\title{
Sexual Dimorphism Using the Interstyloid Distances and Clinical Implication for Elongated Styloid Process in Northeastern Thailand
}

\author{
Dimorfismo Sexual Usando la Distancia Inter-Estiloide y la Implicación \\ Clínica del Proceso Estiloides Elongado en el Noreste de Tailandia
}

\author{
Waraporn Sakaew; Tansita Arnanteerakul; Somsuda Somintara; Somsiri Ratanasuwon; Nongnut Uabundit; \\ Sittichai Iamsaard; Kowit Chaisiwamongkol; Amnart Chaichun \& Wiphawi Hipkaeo
}

SAKAEW, W.; ARNANTEERAKUL, T.; SOMINTARA, S.; RATANASUWON, S.: UABUNDIT, N.; IAMSAARD, S.; CHAISIWAMONGKOL, K.; CHAICHUN, A. \& HIPKAEO, W. Sexual dimorphism using the interstyloid distances and clinical implication for elongated styloid process in Northeastern Thailand. Int. J. Morphol., 34(4):1223-1227, 2016.

SUMMARY: Skeletal remains are crucial in forensic identification of the sex, especially human skulls including the styloid process, a bony projection from the skull. Hence, the objectives of the present study were undertaken to assess the value of the styloid process for the sex identification of unknown skulls and also to investigate the prevalence of elongated styloid process in 102 human dry skulls from the northeast Thai population. As a result, the interstyloid distances at both base and tip of the styloid processes were found to be significantly different between male and female specimens, although no significant difference was found in the length of the styloid process between males and females. In addition, the occurrence of the elongated styloid process was not associated with the gender, although its prevalent laterality on the left was recognized. It is suggested that the styloid process can be applied to the sex identification by measuring the interstyloid distance at the base or the tip of these processes.

KEY WORDS: Styloid process; Elongated styloid process; Interstyloid distance; Sex identification.

\section{INTRODUCTION}

The sex estimation is one of the most important steps in identification of the biological profile of the dismembered and skeletal remains. The accuracy of skeletal sex estimation relies on the sexual dimorphism exhibited by the human body. From previous studies, the pelvis and skull have been considered the most reliable for identification of the sex of unknown remains (Krogman \& Iscan, 1986). Additionally, studies on the sex estimation have been conducted on various skeletal elements such as the scapula, sternum, clavicle, patella, hand and foot bones (Vasiliki et al., 2012; Singh et al., 2012; Smith, 1996; Viwatpinyo et al., 2014). However, no studies have been focused on the sex estimation using the styloid process.

The styloid process is a cylindrical bony projection extending from the petrous portion of the temporal bone. It lies in front of the stylomastoid foramen and projects downwards, forwards, and slightly towards the medial side.
The location of the apex of the styloid process is clinically important, which is located between internal carotid and external carotid arteries, posterolateral to the tonsillar fossa and laterally from the pharyngeal wall. There are many structures surrounding the styloid process, such as the facial nerve crosses to the base and external carotid artery crosses its apex of this process before embedded in the parotid gland. In addition, three muscles and two ligaments are attached to the styloid process. Stylopharyngeus, stylohyoid and styloglossus muscles are attached to the base, middle part and tip of the styloid process, respectively. The stylohyoid and stylomandibular ligaments extend from the tip of the styloid process to the hyoid bone and the angle of mandible, respectively (Standring, 2008).

The normal adult styloid process is approximately $20-30 \mathrm{~mm}$ in length. The styloid process is generally regarded as elongated when it is longer than $30 \mathrm{~mm}$ (Eagle, 1962). 
The elongated styloid process can compress some neural or vascular structures of the pharynx. Resulting pains were first described by Eagle and referred as Engle's syndrome. Symptoms associated with an Engle's syndrome, in addition to such as pharyngeal pain, include dysphagia, tinnitus and foreign body sensation in the throat. The symptoms also include changes in the voice and reduces in the range of the mandibular opening (Dinkar \& Amonkar, 2003).

The purposes of this study are: 1) to estimate the sexual dimorphism of the styloid process, and 2) to investigate the prevalence of the elongated styloid process in a Thai population living in the northeast region.

\section{MATERIAL AND METHOD}

A total of 102 adult dry human skulls with intact styloid processes (50 males and 52 females) were derived from donated cadavers in the Department of Anatomy, Faculty of Medicine, Khon kean University, Thailand. The styloid process length and the interstyloid distance of the skull between the right and left sides were measured using a digital Vernier caliper. For the length of the styloid process, the measurement was taken from the base of the skull to the tip of the styloid process (Fig. 1).

For the interstyloid distance at the base of the skull, the measurement was done on the distance between the bases of 2 styloid processes (Fig. 2). While the interstyloid distance at the tip of the skull was measured the distance between the tips of 2 styloid processes.

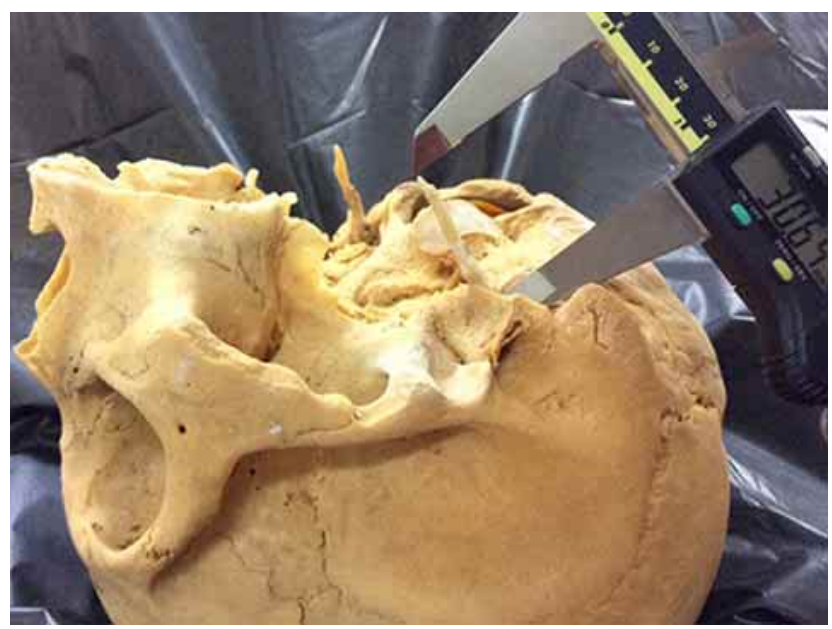

Fig. 1. Length of the styloid process from the base to the apex of the process.

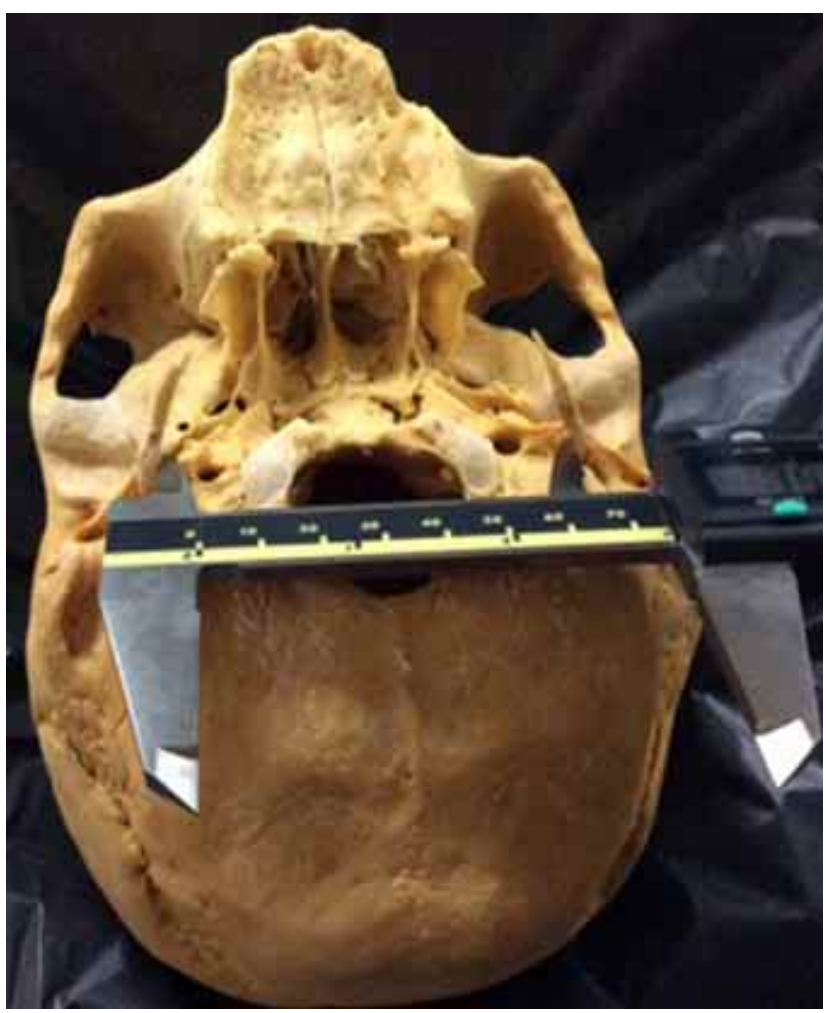

Fig. 2. The interstyloid distance at the base of two styloid processes.

Each measurement was performed three times and averaged them. The values were statistically analyzed with the statistical package for social science (SPSS) version 17.0 (SPSS Inc., Chicago, Illinois, USA). The data were analyzed using the student $\mathrm{t}$-test and $\mathrm{P}$ values less than 0.05 were accepted as statistically significant.

\section{RESULTS}

Among the total 102 specimens, the length of the styloid process was highly varied from $8.75 \mathrm{~mm}$ as the shortest to $42.02 \mathrm{~mm}$ as the longest (Table I). The mean values of the length were $24.79 \pm 6.80 \mathrm{~mm}$ and $24.53 \pm 6.20$ $\mathrm{mm}$ on the right side and $24.54 \pm 6.58 \mathrm{~mm}$ and $24.92 \pm 6.04$ $\mathrm{mm}$ on the left side in male and female, respectively. While its mean values on the right side in female seems to be greater than that in male, its value on the left side greater in females. However, the differences of the styloid process length were statistically non-significant between males and females on both right and left sides $(\mathrm{P}>0.05)$.

The interstyloid distances of the skull at the base and the tip of the styloid processes were represented in Table II. Whereas the means of the distances at the base and the tip 
SAKAEW, W.; ARNANTEERAKUL, T.; SOMINTARA, S.; RATANASUWON, S.: UABUNDIT, N.; IAMSAARD, S.; CHAISIWAMONGKOL, K.; CHAICHUN, A. \& HIPKAEO, W. Sexual dimorphism using the interstyloid distances and clinical implication for elongated styloid process in Northeastern Thailand. Int. J. Morphol., 34(4):1223-1227, 2016.

Table I. Sex comparison of the styloid process lengths.

\begin{tabular}{llcccc}
\hline Locations & Sex & Range in $\mathbf{~ m m}$ & Mean in $\mathbf{~ m m}$ & SD & $\boldsymbol{P}$-va \\
\hline \multirow{2}{*}{ Right } & Male & $8.75-42.02$ & 24.79 & 6.80 & 0.84 \\
& Female & $9.50-34.49$ & 24.53 & 6.20 & \\
\multirow{2}{*}{ eft } & Male & $10.89-37.46$ & 24.54 & 6.58 & 0.761 \\
& Female & $10.13-40.20$ & 24.92 & 6.04 & \\
\hline
\end{tabular}

Table II. Sex comparison of the interstyloid distances

\begin{tabular}{llccc}
\hline Locations & Sex & Mean in $\mathbf{~ m m}$ & SD & $\boldsymbol{P}$-value \\
\hline Interstyloid distance at base & Male & 80.24 & 4.00 & \multirow{2}{*}{$0.001^{*}$} \\
of the styloid processes & Female & 77.24 & 5.12 & \\
Interstyloid distance at tip & Male & 68.46 & 5.80 & \multirow{2}{*}{$0.002^{*}$} \\
of the styloid processes & Female & 64.66 & 6.08 & \\
\hline
\end{tabular}

Table III.Sex incidence of the elongated styloid process.

\begin{tabular}{lcc}
\hline Sex & $\begin{array}{c}\text { Normal styloid } \\
\text { p rocess }\end{array}$ & $\begin{array}{c}\text { Elongated styloid } \\
\text { process }\end{array}$ \\
\hline Male & $38(37.25 \%)$ & $14(13.73 \%)$ \\
Female & $37(36.27 \%)$ & $13(12.75 \%)$ \\
\hline
\end{tabular}

Table IV. Sex prevalence of the elongated styloid process.

\begin{tabular}{|c|c|c|}
\hline \multirow{2}{*}{ Sex } & \multicolumn{2}{|c|}{ Elongated styloid process } \\
\hline & Bilateral & Unilateral \\
\hline Male & $6(5.88 \%)$ & $8(7.84 \%)$ \\
\hline Female & $4(3.92 \%)$ & $9(8.82 \%)$ \\
\hline
\end{tabular}

Table V. Sex prevalence of unilateral elongated styloid process.

\begin{tabular}{lcc}
\hline Sex & $\begin{array}{c}\text { Unilateral elongated styloid process } \\
\text { Right }\end{array}$ & Left \\
\hline Male & $3(2.94 \%)$ & $5(4.90 \%)$ \\
Female & $4(3.92 \%)$ & $5(4.90 \%)$ \\
\hline
\end{tabular}

were $80.24 \pm 4.00 \mathrm{~mm}$ and $68.46 \pm 5.80$, respectively, in male, those in female were $77.24 \pm 5.12 \mathrm{~mm}$ and $64.66 \pm$ 6.08 , respectively. These differences between male and female were statistically significant differences both at the base $(\mathrm{P}<0.05)$ and the tip $(\mathrm{P}<0.05)$.

Tables III, IV and V shows the incidences of the elongated styloid process. Of the total 102 specimens, 27 skulls $(26.47 \%)$ had elongated styloid processes with 14 out of 52 skulls $(13.73 \%)$ in male and 13 out of 50 skulls $(12.75 \%)$ in female. Bilateral elongated styloid processes were found in $6(5.88 \%)$ of the 14 male skulls and 4 (3.92 $\%$ ) of the total 13 female skulls. As for the laterality of unilateral elongated styloid processes, the elongated were found in 3 skulls $(2.94 \%)$ in male and 4 skulls $(3.92 \%)$ in female at the right side.

\section{DISCUSSION}

The identification of the sex of skeletal remains is important in the execution of the forensic anthropological examination. For this purpose, the information on sexual dimorphism of human skeleton is useful in terms of the morphology differences as well as the larger size of male (Krogman \& Iscan). In this regard, Krogman \& Iscan have stated that the sex identification with $100 \%$ accuracy is possible when the whole skeleton is utilized, while the $98 \%$ accuracy is possible

by using the pelvis and the skull, the $95 \%$ accuracy by the pelvis alone, and $92 \%$ by the skull alone. Furthermore, there have been studies to estimate the value for sex identification of various parts of the skeleton such as patella, mastoid process, scapula and clavicle, and first rib (Introna et al., 1998; Vasiliki et al., 2012; Kubicka \& Piontek, 2016). However, no estimation of the value has so far been done about the styloid process.

According to previous reports, the normal length of the styloid process is varying in different geological regions, such as 2.50-3.00 $\mathrm{mm}$ in Europe (Eagle, 1962) and $24.12 \pm 7.28 \mathrm{~mm}$ in Thai (Promthale et al., 2012). With regard to the sex dimorphism, Hussain et al. (2011) have reported that its length in male is larger than that in female at both right and left sides with a statistically significance. In the present study, however, no statistical significance was found in the sex difference in the length of the styloid process. Although some differences seemed to be present in terms of the laterality.

The styloid process with its length larger than 30 $\mathrm{mm}$ is generally regarded as the elongated styloid process and a representative of Engle's syndrome (Balbuena et al., 1997). Although the skeletal growth is a complex biological phenomenon influenced by many factors such as genotype, hormones, nutrition, ecology, energy levels and medical care (Charisi et al., 2011; Raghavendra Babu et al., 2012) The commonly accepted cause of the styloid process elongation is a congenital elongation and ossification of the stylohyoid ligament. The Engle's syndrome characterized by the elongated styloid process was first described by Eagle (1962) and it is a rare disease in which the elongated process compresses neurovascular structures surrounding it. This syndrome is classified into 2 types; one of the two, termed the classical type is characterized by a persistent pain in the throat and ear, and a foreign body sensation in the throat. The other type is characterized 
SAKAEW, W.; ARNANTEERAKUL, T.; SOMINTARA, S.; RATANASUWON, S.: UABUNDIT, N.; IAMSAARD, S.; CHAISIWAMONGKOL, K.; CHAICHUN, A. \& HIPKAEO, W. Sexual dimorphism using the interstyloid distances and clinical implication for elongated styloid process in Northeastern Thailand. Int. J. Morphol., 34(4):1223-1227, 2016.

by dizziness and headache probably due to the compression of the carotid artery by the elongated processes. For differential diagnoses of Engle's syndrome, attention should be paid to oral and dental diseases, temporomandibular disorders, and tumors in the oropharynx and laryngopharynx (Eagle, 1948). Some authors have reported that an abnormal angulation of the styloid process may be responsible for the compression of the nearby structures rather than the elongation itself of this process (Rathva et al., 2013).

With regard to the occurrence frequency of the elongated styloid process, the present value of $26.47 \%$ in north east Thai population is lower than that of Brazilian reported by Vieira et al. (2015) and de Andrade et al. (2012) as $76 \%$. However it was slightly upper than the reported of Rizzatti-Barbosa et al. (2005) and Leite et al. (1988), as $20 \%$ and $19.56 \%$, respectively.

Regarding gender, the elongated styloid process or Eagle's syndrome occurred more frequently in females (Woolery, 1990). In contrast, reported that styloid processes were elongated more in males than females (Bozkir et al., 1999). Our study found no relationship of gender to an Engle's syndrome in agreement with Ilgüy et al. (2005). Although the elongated styloid process can occur unilaterally or bilaterally. It has been previously reported that elongation styloid process were bilateral more than unilateral (Bozkir et al.; Ilguiy et al.). We found that the unilateral elongated styloid process was more frequently found on the left than the right side in both males and females.
To the best of our knowledge this study is the first to be conducted styloid process for sex determination. We found the statistically significant differences of the interstyloid distance at both the base $(\mathrm{P}<0.05)$ and the tip $(\mathrm{P}<0.05)$ of the processes. The skull being one of the most accurate bones for sex differentiation (Krogman \& Iscan). In fact, the styloid process is an elongated bony projection from the petrous portion of the temporal bone (Dinkar \& Amonkar). Therefore, the results of this study indicate that it is possible to use the interstyloid distance at both the base and the tip of the processes for sex estimation.

The results of this study indicated that the styloid process has a good potential for sex identification. By measuring the interstyloid distance at both the base and the tip of these processes. The knowledge length of the styloid process and prevalence of the elongated styloid process are important and useful to the anatomists, anthropologists, radiologists, and clinicians.

\section{ACKNOWLEDGEMENTS}

This research was financially supported. We also would like to thank Department of Anatomy, by Faculty of Medicine, Khon kaen University, Thailand. Special thanks are express gratitude Miss Rawan Sankot for her statistical guidance, Mr. Yuthasak Chinkamharn and Mr. Sayan Noichomphoo for providing the skeletal samples and Prof. Hisatake Kondo for manuscript proof reading.

SAKAEW, W.; ARNANTEERAKUL, T.; SOMINTARA, S.; RATANASUWON, S.: UABUNDIT, N.; IAMSAARD, S.; CHAISIWAMONGKOL, K.; CHAICHUN, A. \& HIPKAEO, W. Dimorfismo sexual usando la distancia inter-estiloide y la implicación clínica del proceso estiloides elongado en el Noreste de Tailandia. Int. J. Morphol., 34(4):1223-1227, 2016.

RESUMEN: Los restos óseos son cruciales para la identificación forense del sexo, especialmente en los cráneos humanos, incluyendo el proceso estiloides, una proyección ósea del cráneo. Por lo tanto, los objetivos del presente estudio consistieron en evaluar el valor del proceso estiloides en la identificación del sexo de cráneos desconocidos y también para investigar la prevalencia del proceso estiloides elongado en 102 cráneos secos humanos de la población del Noreste de Tailandia. Como resultado, se encontró que las distancias inter-estiloides tanto en la base y la punta de los procesos estiloides eran significativamente diferentes entre las muestras de hombres y mujeres, aunque no se encontró diferencia significativa en la presencia del proceso estiloides entre ambos. Además, la aparición del proceso estiloides elongado no se asoció con el sexo, aún cuando se observó su prevalencia en el lado izquierdo. Sugerimos que el proceso estiloides se puede utilizar en la identificación del sexo mediante la medición de la distancia inter-estiloide en la base o en la punta de estos procesos.

PALABRAS ClAVE: Proceso estiloides; Proceso estiloides elongado; Distancia inter-estiloide Identificación del sexo.

\section{REFERENCES}

Balbuena, L. Jr.; Hayes, D.; Ramirez, S. G. \& Johnson, R. Eagle's syndrome (elongated styloid process). South Med. J., 90(3):331-4, 1997.
Bozkir, M. G.; Boga, H. \& Dere, F. The evaluation of elongated styloid process in panoramic radiographs in edentulous patients. Tr. J. Med. Sci., 29:481-5, 1999. 
SAKAEW, W.; ARNANTEERAKUL, T.; SOMINTARA, S.; RATANASUWON, S.: UABUNDIT, N.; IAMSAARD, S.; CHAISIWAMONGKOL, K.; CHAICHUN, A. \& HIPKAEO, W. Sexual dimorphism using the interstyloid distances and clinical implication for elongated styloid process in Northeastern Thailand. Int. J. Morphol., 34(4):1223-1227, 2016.

Charisi, D.; Eliopoulos, C.; Vanna, V.; Koilias, C. G. \& Manolis, S. K. Sexual dimorphism of the arm bones in a modern greek population. J. Forensic Sci., 56(1):10-8, 2011.

de Andrade, K. M.; Rodrigues, C. A.; Watanabe, P. C. \& Mazzetto, M. O. Styloid process elongation and calcification in subjects with tmd: clinical and radiographic aspects. Braz. Dent. J., 23(4):443-50, 2012.

Dinkar \& Amonkar, S. S. Eagle's syndrome: review of literature and case report. Indian J. Dent. Res., 14(3):162-8, 2003.

Eagle, W. W. Elongated styloid process; further observations and a new syndrome. Arch. Otolaryngol., 47(5):630-40, 1948.

Eagle, W. W. The symptoms, diagnosis and treatment of the elongated styloid process. Am. Surg., 28:1-5, 1962.

Hussain, S. S.; Muralidhar, P. S. \& Haseena, S. Study the length of styloid process in South Indian adults dry skulls. J. Pharm. Sci. Res., 3(9):1456-9, 2011.

Ilgüy, M.; Ilgüy, D.; Güler, N. \& Bayirli, G. Incidence of the type and calcification patterns in patients with elongated styloid process. J. Int. Med. Res., 33(1):96-102, 2005.

Introna, F. Jr.; Di Vella, G. \& Campobasso, C. P. Sex determination by discriminant analysis of patella measurements. Forensic Sci. Int., 95(1):39-45, 1998.

Krogman, W. M. \& Iscan, M. Y. The Human Skeleton in Forensic Medicine. $2^{\text {nd }}$ ed. Springfield, Charles C. Thomas Publisher, 1986.

Kubicka, A. M. \& Piontek, J. Sex estimation from measurements of the first rib in a contemporary Polish population. Int. J. Legal Med., 130(1):265-72, 2016.

Leite, H. F.; Niccoli Filho, W. D.; Liberti, E. A.; Madeira, M. C. \& Simöes, S. Prevalência do processo estilóide alongado em crânios humanos. Rev. Odontol. U. N. E. S. P., 17(1):145-51, 1988.

Promthale, P.; Chaisuksunt, V.; Rungruang, T.; Apinhasmit, W. \& Chompoopong, S. Anatomical consideration of length and angulation of the styloid process and their significances for eagle's syndrome in Thais. Siriraj Med. J., 64(Suppl. 1):S303, 2012.

Raghavendra Babu, Y. P.; Kanchan, T.; Attiku, Y.; Dixit, P. N. \& Kotian, M. S. Sex estimation from foramen magnum dimensions in an Indian population. J. Forensic Leg. Med., 19(3):162-167, 2012.

Rathva, A.; Kubavat, D. M. \& Nagar, S. K. Study of styloid process: Anatomical variations in length, angulation and distance between the two styloid processes. I. J. R. T. S. A. T., 8(2):10912,2013
Rizzatti-Barbosa, C. M.; Ribeiro, M. C.; Silva-Concilio, L. R.; Di Hipolito, O. \& Ambrosano, G. M. Is an elongated stylohyoid process prevalent in the elderly? A radiographic study in a Brazilian population. Gerodontology, 22(2):112-5, 2005.

Singh, J.; Pathak, R. K. \& Singh, D. Morphometric sex determination from various sternal widths of Northwest Indian sternums collected from autopsy cadavers: A comparison of sexing methods. Egypt. J. Forensic Sci., 2(1):18-28, 2012.

Smith, S. L. Attribution of hand bones to sex and population groups. J. Forensic Sci., 41(3):469-77, 1996.

Standring, S. Gray's Anatomy. The Anatomical Basis of Clinical Practice. $40^{\text {th }}$ ed. Edingburgh, Churchill Livingstone/Elsevier, 2008.

Vieira, E. M.; Guedes, O. A.; Morais, S. D.; Musis, C. R.; Albuquerque, P. A. \& Borges, Á. H. Prevalence of Elongated Styloid Process in a Central Brazilian Population. J. Clin. Diagn. Res., 9(9):ZC90-2, 2015.

Viwatpinyo, K.; Case, D. T. \& Mahakkanukrauh, P. Sex estimation from the navicular bone in a Thai population. Siriraj Med. J., 66(6):210-8, 2014.

Woolery, W. A. The diagnostic challenge of styloid elongation (Eagle's syndrome). J. Am. Osteopath. Assoc., 90(1):88-9, 1990.

Correspondence to:

Waraporn Sakaew

Department of Anatomy

Faculty of Medicine

Khon Kaen University

THAILAND

Email: sakaew@gmail.com

Received: 04-04-2016

Accepted: 23-08-2016 